\section{Conflict of inte
Davis scientist steps away from grant}

\section{Washington}

In a move that again reflects tensions between academic and commercial interests in biotechnology, a prominent plant geneticist at the University of California's Davis campus has agreed to step down from a multi-million dollar sponsored research contract financed by a large fertilizer company because of a potential conflict of interest with a private research company in which both he and the fertilizer manufacturer are also involved.

Dr Ray Valentine, internationally known for his research on the isolation of the nif genes present in plant-colonizing bacteria and responsible for the nitrogenfixing properties of some plants, has also offered to resign from the university's Agricultural Experiment Station, where the sponsored research would be carried out. Although remaining on the faculty, where he is professor of plant biology, such a move would increase his responsibility for undergraduate and postgraduate teaching and reduce his involvement with university research programmes.

Dr Valentine's offer to restrict his university-based research follows concerns raised by Dr Charles Hess, dean of the university's College of Agricultural and Environmental Sciences, over the implications of a five-year, $\$ 2.3$ million research contract signed in July with Allied Chemical Corporation, for which Dr Valentine was to have been a principal investigator. The research under this contract would explore ways in which the bacterial genes discovered by Dr Valentine might be transferred to other plants to enable such plants fix their own nitrogen.

A few days after the deal with Allied Chemical Corporation was signed, the company announced that it had agreed to purchase a 20 per cent equity interest, at a cost of $\$ 2$ million, in a Davis-based company called Calgene which $\mathrm{Dr}$ Valentine had helped to set up and of which he is a vice-president.

On learning this news, Dr Hess told Dr Valentine that, as a result of concern among faculty members about potential conflicts of interest he would either have to withdraw from his involvement in the Allied Chemical grant to the university, or from Calgene. Dean Hess also announced that he was holding up the company's grant until an acceptable arrangement had been made.

Dean Hess has suggested two possible statements of principle which the faculty might use as a framework for establishing

outside contracts. One would be that individuals with appointments in the Agricultural Experiment Station "shall not accept gifts, grants or research contracts with private firms in which they have an equity interest or serve as a consultant" a condition that would have applied to Dr Valentine's case. Dean Hess has also suggested that such individuals "shall not have an equity interest in private firms whose research programs are the same as the individual's Experiment Station research programme".

Emphasizing his complete confidence in the integrity of Dr Valentine, Dean Hess said that as the college and experimental station were funded primarily from public sources there was also concern about "whether these apparent conflicts of interest might jeopardize the support that we get from tax funds if people began to feel that the return from the research was being realized by private investors".

Calgene officials for their part have

\title{
Technology assessment wins new friends
}

\section{Washington}

Two years off its tenth birthday, the United States Congress's Office of Technology Assessment (OTA) at last seems to be coming of age. By adopting a more pragmatic outlook OTA has generated a political and scientific credibility that makes its prospects more secure than ever before.

The change has its critics. "OTA is turning out good craft pieces that serve the interests of clients, but there is still a latent demand for something which is more policy- and futures-rich"' says Dr Joseph Coates, who was among the original staff members and recently left to establish his own consultancy firm.

But evidence of the new-found stability, which broadly coincides with the reign of OTA's present director, Dr John Gibbons, previously head of the Energy, Environment and Resources Center at the University of Tennessee, was shown last week by the willingness of a Republican-dominated Senate, in a time of reduced federal spending, to increase the OTA's budget by 7.5 per cent next year to $\$ 12$ million. Even though this will barely allow OTA to keep up with inflation, it compares with the budget to which the office has been held between 1980 and 1981 .

When OTA was established by Congress in 1972, finally coming into being in November 1973, many saw it - with some justification - as a vehicle through which Democrat legislators hoped to challenge the scientific and technical decisions of the Nixon Administration following the demise of the Office of Science and Technology and the President's Science Advisory Committee.

OTA's new-found friends, however, denied that there would necessarily be a conflict of interest. Although major funding has been received from Allied Chemical, they insist that their main research interest will be on how to improve the efficiency of fertilizers, rather than looking at plants themselves, as researchers at the experiment station will be doing.

Faculty members at Davis will meet next month to discuss Dean Hess's proposals. Meanwhile Dr Valentine's future relationship with the university remains uncertain. Dean Hess says that he intends to "discuss" Dr Valentine's offer to resign from the experiment station completely rather than just withdraw from the Allied Chemical project. The university is keen to avoid any public criticism about conflicts of interest. At the same time, it is reluctant to put off potential corporate sponsors of its research which are becoming an increasingly important source of funding as federal and state financing for research begins to contract.

David Dickson

include conservative Republicans such as Senator Paul Laxalt of Nevada. Senator Laxalt is said to have been impressed by a recent study carried out by OTA comparing different basing modes for the MX missile which point out the advantages and drawbacks of each without endorsing a

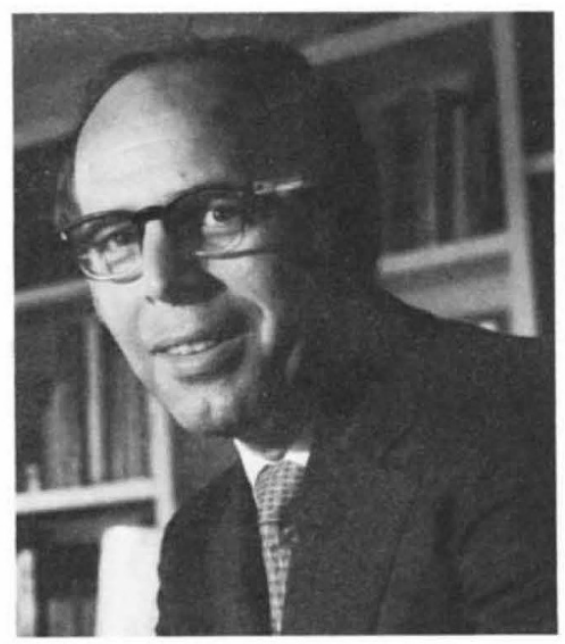

Dr John Gibbons - forging links

particular design, issues directly pertinent to the debate about placing the missiles in his home state.

The importance of such friends emerged two weeks ago, when they helped to head off an attempt by Senator Mack Mattingly, chairman of the Senate appropriations subcommittee responsible for legislative affairs, to kill future funding for the OTA on the grounds that its studies duplicate the work of other bodies such as the Congressional Research Service.

It was a charge that was strongly denied by Dr Gibbons in hearings on the OTA 
budget earlier this year. He pointed out that the cases quoted by Mr Mattingly for example of consulting firms carrying out the same work for different agencies were several years old, and that with a tighter management structure and more narrowly defined missions, OTA was now beginning to demonstrate unique value to Congress.

Much to OTA's relief, Senator Mattingly did not take his case to the floor of the Senate, and OTA's 1982 budget is now secure. "I presume it did not come up because a lot of people on both sides of the aisle have come to see OTA as a useful and important analytical tool", said Dr Gibbons last week.

Much of the recent work, both long-term and short-term, has impressed OTA's congressional clients. "Some of their stuff is really excellent, particularly in the energy field" says one staff member of the House Science and Technology Committee. A recent report, Impacts of Applied Genetics, an analysis of the economic and commercial implications of genetic engineering applied to microorganisms, plants and animals, has been widely praised and recently reached the "top ten list" of government publications.

One secret of OTA's survival seems to be its greater awareness of the limits within which it can safely operate. The genetic engineering study, for example, avoided all discussion of the human apllications as "beyond its scope", and the MX study, while studying the "socio-economic" implications of the weapons' deployment, did not discuss political factors such as the full implications of local resistance. Dr Gibbons explains this pragmatically. "Our job is to narrow the issues that must be fought out rather than to tell the politicians what they should do", he says. He talks of breaking problems down into "bite-size" pieces, referring, for example, to recent OTA studies on energy utilization and demand.

Dr Gibbons is currently trying to forge closer links with the National Academy of Sciences, as well as discussing ways of complementing the policy orientations of the Office of Science and Technology Policy. Drawing technology assessment more closely into the traditional nexus of political decision-making may have disenchanted some of its earlier enthusiasts. But it has proved to be a formula for political survival. David Dickson

\section{Islamic science}

\section{Radicals agree}

Islam and a handful of radical Western scientists came together in a royal palace last week, leading to what one Islamic scholar called a "breakthrough in Islamic studies".

The objective of the meeting was to develop a critique of the role of science and technology in society as seen from an
Islamic perspective and using Islamic values. This is not a matter of counting Islamic angels on a needle point, but an issue central to the 42-riation Muslim world seeking both to absorb the fruits of science and technology without too much social disturbance, and to rally behind the flag and philosophy of Islam. The study was the first in a series of science in Islam and the West being organized by the International Federation of Institutes for Advanced Study (IFIAS), set up by the Nobel Foundation to consider issues of academic weight and world importance. King Gustav of Sweden has given the federation a palace as headquarters and conference centre.

Inspiration for the conference came from Ziauddin Sardar, a young Londoner born of Pakistani parents (and one-time correspondent of Nature) who has a passion for Islam and the issues of development in the Muslim world. $\mathrm{He}$ appears to have achieved a rapprochement between Westerners and the senior and devout Muslim scientists at the meeting.

Initially the meeting seemed likely to founder on the rock of the Muslim insistence on the purity of any search for knowledge. Islam directs the faithful to seek knowledge of the natural world, and inspiration in it: the world is the work of God. This concept, while appealing to Western scientific egos, seemed incomplete to the radicals - to whom some kinds of scientific knowledge were like a "second bite of the apple". This was heresy to the Muslims.

\section{Distinctive development}

The delicacy of politics in the Muslim world helps to explain why it has taken three years to install the director-general of the Islamic Foundation for Science, Technology and Development, Dr Ali Kettani, in the Jeddah headquarters.

Kettani has to deal with 42 diverse Muslim nations embracing Africa, the OPEC states and the Far East - each with its own internal political problems, its own approach to Islam and its own goal in "development". Kettani's goal is to forge an Islamic brotherhood of scientists and technologists, who would turn to each other, rather than to the West, to solve problems.

The foundation has been promised an initial $\$ 50$ million for $2-3$ years recommended by the Organization of the Islamic Conference (of which $\$ 15$ million has already been paid by Saudi Arabia). There is to be a staff of some $30-40$ and a charter which requires the foundation "to ensure that all member countries ..., both individually and collectively, make the greatest possible use of science and technology (including the social sciences) in the formulation and implementation of their socio-economic plans, keeping in mind the need to consolidate the unique Islamic personality and character".
The Westerners would also not allow a firm distinction between the search for knowledge and its use, which would have solved the dilemma. The idea was simplistic, they said: half the world's science is attributable to defence and industrial research budgets, even if that science is, in its minutiae, "fundamental".

The solution came from Dr Ali Kettani, recently appointed director of the Islamic Foundation for Science, Technology and Development (see box). In Islam, both the ends and means of an individual's actions must be "hallal" (allowed), so knowledge sought within a context of "harram" (forbidden) use would also be forbidden.

The social context and consequences of science could also be considered within Islam, the meeting judged, using precisely defined Quranic concepts such as "adl" (equity), "zulm" (oppression), "muslah" (public interest) and "dyah" (waste).

A measure of the success of the meeting was that the participants tore up their papers, prepared before the conference, and which were to have been the basis of a book, promising to rewrite them in the light of what they had learned. Subsequent meetings in the seminar series will turn to more practical technical issues, such as energy and environment (to be held in Riyadh), habitation, agriculture, health, and industry and mass production.

Robert Walgate

\section{London science centre}

\section{No cash ahead}

The new London Science Centre is appealing for money to keep going for a second year. The centre was established last April by the Foundation for Science and Technology with about $£ 50,000$ of donations from learned societies and industry. It is now looking for a further $£ 200,000$ to tide it over until it becomes self-financing.

The centre's aim is to provide facilities for small learned societies whose existence is threatened by the high cost of central London. So far, interest has been modest. Only twenty-six societies have joined, and are entitled to pay less than the going rate for assistance with their day-to-day administration. The main facilities on offer are two small conference rooms and five offices, together with secretarial assistance, at the centre's rented headquarters in the Royal Society of Arts.

The centre's preoccupation during its first six months has been to take over the role of liason among learned societies from the Royal Society. But plans for the future are more ambitious. The idea is that the centre will not only of fer facilities such as word-processing and computerized membership lists, but will become a focus for interdisciplinary communication.

Even so, its centre is the residue of a far more ambitious scheme to emulate the Clunies Ross Memorial Foundation set up 